\title{
12
}

\section{Christianity and kultura: Visions and pastoral projects ${ }^{1}$}

\author{
Kelly Silva
}

The revival of customary practices, known as kultura, adat or usos $e$ costumes is considered one of the main effects of Timor-Leste's restoration of independence, according to various ethnographic studies (e.g. Barnes 2010; Bovensiepen 2015; McWilliam et al. 2014; Silva 2013; Silva and Simião 2012). It is also a common argument among agents of the Catholic Church. For them, however, such a revival generates not only epistemic anxiety (as it does for researchers) but considerable political worry. This phenomenon is seen as a threat to the hegemony of Catholic Christianity in a country that is, in relative terms, the largest Catholic country in Southeast Asia.

This chapter explores the relationship between kultura and Catholicism, addressing discourses and political projects that respond to the revival of kultura in Timor-Leste, and examining the perception of some East Timorese priests that Catholicism is being weakened by this revival. ${ }^{2}$ From the priests' perspectives, the relations between kultura and Christianity are

1 This article is an outcome of research supported by the Brazilian National Council for Scientific and Technological Development (CNPq) by means of grant nos 307043/2012-6, 457845/20147 and 310991/2015-3. I have also benefited from a sabbatical year at The Australian National University under the School of Culture, Language and History.

2 In Silva (2013), I discuss - with regard to marriage negotiations in Dili - how kultura has encompassed Christianity. 
associated with conversion to Christianity. They expect that conversion to Christianity implies discontinuity - a break with practices and beliefs in local spiritual agents (cf. Keane 2007). I examine how my interlocutors try to explain the continuity of Timorese people's commitments to these institutions and their agents. In other words, how they try to make sense of the way in which adherence to Christianity is not effecting (nor, for some, should it effect) discontinuity or rupture. Furthermore, I explore how Catholic clergy attribute the revival of kultura to what they see as a superficial, formalist, passive and low-quality adherence to Catholicism by some Timorese people. Given this fact, some of my interlocutors present projects for purification and monopolisation of faith (Latour 1994) to confront the 'spiritual ecologies' (Palmer 2015), which characterise the mystic practices of most people. ${ }^{3}$ Nevertheless, not all clergy in TimorLeste agree with these attempts to rid Catholicism of the remnants of customary practices; there is no overall consensus on the appropriate relationship between kultura and Catholicism. There are ranks within the Church that defend the coexistence between kultura and Christianity, arguing in favour of the need for inculturation.

I identify among my interlocutors three distinct projects that shape the relationship between kultura and Christianity and motivate interactions of clergy with their parishioners: the first, a project for a tactical use of kultura as a transitory means for the introduction and strengthening of Christianity; the second, a project that supports an enduring coexistence and mutual reinforcement of kultura and of Christianity, with some selectivity; and the third, a project that seeks the extinction of kultura, because of its supposed incompatibility with Christianity.

Such projects cast light on the diverse arrangements the relations between kultura and Christianity may take in the future; these projects thus entail visions of what the future of religious life in Timor-Leste should look like. Further, they also express the different trends of cultural change in the

3 As carved out by Latour (1994: 16), purification consists of processes of separation and imposition of exclusive ontological frontiers and limits of power among the various experiences, beings and domains that compose social life. By means of these processes of separation, these agencies are either inscribed to certain typical-ideal places for their existence or configurations considered to be legitimate are projected onto them. In this context, one highlights that purification processes are political instruments that produce multiple power effects. Oppositions such as nature and culture, religion and popular beliefs, traditional and modern, politics and science, justice and power, human and non-human, civilised and non-civilised are examples of this separation process. 
country. ${ }^{4}$ It seems that if the project supporting the mutual enforcement of kultura and Christianity will end up being the predominant one, we will see the consolidation of kultura and Catholicism as separate yet equally important domains of agency, following the same trend existing in regions of Indonesia (Howell 2001). On the other hand, if the tactical use of kultura to strengthen Christianity was to gain prominence, Christianity would be likely to encompass kultura in the future. Finally, the project aiming to extinguish kultura points to a historical development in which people would internalise an alienated consciousness about their past, present and future, similar to that which Robbins (2004) identified in the Urapmin population (of Papua New Guinea's West Sepik province) in the past decade. This is because such a project is framed by the expectation of rupture with a previous order that is considered morally inferior, while still remaining present in people's modes of social reproduction. Of course, we do not have any means of predicting the future. However, as Bovensiepen (Chapter 6) highlights, such disparate visions of the future affect people's actions and choices in the present.

As in other colonial frontiers, the words custom, adat, kultura or usos e costumes (Bourchier 2007; Davidson and Henley 2008; Mamdani 1998; Roque 2011) were introduced and consolidated in Timor-Leste as contrasting and inter-ethnic categories with floating meanings (Silva and Simião 2017). Most often, these signifiers are used to refer to the practices or values that are perceived to be indigenous or those that are simply different from others deemed foreign. East Timorese people use these categories when they are interested in marking their distinction from others, whether positively or negatively, as do foreign or local agents as self-attributed 'civilising' missionaries, whether religious or civil. From the perspective of some clergy, kultura is also a signifier that evokes reminiscences of pagan and earlier religious practices (cf. Keane 2007), which, it is hoped, will be abandoned as soon as possible so that people understand and truly practise Catholicism. Moreover, it is also important to recognise that kultura is a category of governance, mobilised by different actors with various political objectives (Silva 2014).

Against this background, the chapter is organised in two main sections. The first explores discourses of the Church's agents concerning the nature of conversion and the adherence of East Timorese people to Christianity.

4 Throughout the chapter, I use kultura (with a ' $k$ ') as an emic category, whereas culture (with a 'c') is an etical, analytical concept. 
Arguments about the lack of proper understanding of Christianity and the nature of religious experiences among Timor-Leste people are developed in particular subsections the first part is made up of. In the second section, I analyse three pastoral projects concerning the relationship between kultura and Catholic Christianity. In the concluding remarks, I consider potential future relationships between Christianity and kultura in TimorLeste, briefly considering some trends in Indonesia and Oceania.

Before I proceed, let me make explicit some methodological and theoretical mediations that have organised the production and analysis of the information discussed below. First, my understanding of pastoral project is oriented by Foucault's (2008: 155-174) term 'pastoral power'; namely, the action of guiding people in their ordinary lives by caring for them. Foucault developed the term 'pastoral power' to describe a form of governmentality typical of religious power first placed in the Near East among Hebrews. He maintains it has evolved from ancient times to contemporary days all over the world, largely by means of Christian religious institutions, but not exclusively. The primary objective of pastoral projects is to bring people closer to God by living a Christian life. To that end, the clergy act as mediators; pastoral power is mobile and it legitimises itself by proclaiming it is doing good.

My interest in the relationship between Christianity and kultura developed from a desire to understand practices of marriage exchanges in contemporary Dili. This chapter is based on five interviews I conducted with Timorese priests working in Dili, as well as on interviews published in other sources such as books, the newspaper $A$ voz da Cultura (Voice of culture) and the newsletter Revista Seara. The data discussed was the result of fieldwork carried out in Dili from 2008 to 2013.

\section{Conversion in doubt: Quantity versus quality and the re-evangelising project}

The Catholic Church is frequently mentioned as a key influence in Timor-Leste's colonial history in several important respects: the alliance between Church and state and their role in producing 'civilised people'; the role of Dominican missionaries in maintaining Portuguese sovereignty over Timor in the sixteenth and seventeenth centuries; and the Catholic Church's hegemony in the provision of school education in the period of 
Estado Novo (the New State) ${ }^{5}$ in Portugal (Fernandes 2014). Curiously, however, statistics indicate that only 28 per cent of the population could be considered nominally Christian in the 1970s (Durand 2004: 69).

This situation changed radically during the Indonesian occupation. Pancasila (the five tenets of Indonesian state ideology) and the role the Catholic Church acquired in defending human rights were catalysts for the fact that 89 per cent of Timorese people were registered as Catholic (Durand 2004) by the end of the 1990s. The Timorese resistance strategically referred to the increased numbers of Catholics as a reason for why the territory's independence from Indonesia was necessary, where the majority of the population is nominally Islamic.

Reflecting on this period, one of my interlocutors affirmed that, during the Indonesian occupation, the number of people baptised by the Church was more important than the quality of the conversion. To avoid the conversion of Timorese people to Islam - as Pancasila obliged the adherence of all Indonesian citizens to a monotheist religion - the Catholic Church promoted mass baptisms. According to him, before 1975, missionaries only baptised those people who were properly prepared in rigid re-education processes. As a consequence, the conversions had a distinct quality. After 1975, the Church began to baptise and administer its sacraments in a less controlled manner. The people who requested the sacraments were not subject to rigorous preparation or, perhaps, had no preparation at all. The effects of this policy, he affirmed, are felt today. The conversion of people to Christianity is more formal and superficial than factual, in his terms.

The Catholic Church became more demanding in the post-independence period. As a condition for receiving certain sacraments, today the Church requires that the person has already received the sacraments that precede the one requested. The Catholic Church also expects the parents and/ or descendants of the prospective adherent to have already received the sacraments for which their children were eligible. For example, for someone to marry in Church, they must prove that they were baptised and confirmed into the Catholic Church, that their parents were married or their children baptised. Nevertheless, there were still considerable

5 The New State was a term Antonio Salazar used to describe his government when he was appointed Portugal's prime minister in 1932, the beginning of decades of authoritarian rule. 
difficulties in deepening people's Christian religious practice. According to this interlocutor, Timorese people only invest in the Catholic God a tiny portion of the energy that they invest in kultura.

Another category that is frequently mobilised to give meaning to how the East Timorese experience Christianity is dualism. Some sources understood people to be living between two different worlds: the Christian world and the local one. In the words of one of the priests, 'by day they are Christian, at night they conduct kultura, and they like this. Then they come to Church, confess that they did kultura and feel pardoned'.

Many couples live together and have children before receiving the Church's sacrament of marriage and only arrange their wedding - with the Catholic mass it entails - when they attain the financial resources necessary to conduct the kultura-based marriage exchanges. That fact is often presented as an indicator of their lack of understanding or the superficiality of their conversion to Christianity. It is suggested that people marry in Church more often because of an attachment to social convention than because of a belief in the sacrament. All the priests I talked to believed that, among Timorese people, attention to kultura takes precedence over Christian obligations.

In fact, my conversations with young couples and their families about the dynamics of marriages today confirm kultura's precedence. For them, responding to the expectations of kultura - as expressed in the exchange of goods - is more important than a church ceremony. This is because disrespect for kultura raises the threat of punishment; however, disrespect for the Christian God does not.

\section{The problem of the lack of understanding}

My interlocutors explained the inexistent rupture or discontinuity between local beliefs and Christian ones among Timorese as a lack of understanding, either of Christianity or of kultura. The alleged lack of understanding is said to be responsible for the subordination of Christianity to kultura. In a critical tone, one of my interlocutors affirmed that most people use Christian institutions to support the reproduction of kultura and not the opposite. The great challenge for the Church, in the postcolonial context, would be to invert this logic radically. ${ }^{6}$

6 Lack of understanding is a category of accusation that seeks to promote moral exclusion, as Boarccaech (2013) indicated in his work among Catholic Christians and adherents to the Assembly of God in Ataúro. 
As mentioned above, the allegations of a lack of understanding do not exclusively concern Christianity but also kultura. The diversity of practices considered to be kultura in Timor-Leste, as well as the absence of a written record of these practices, are said to facilitate this easy transition between local and Christian institutions. People do not experience their coexistence as a contradiction because, according to one interlocutor, they do not have a deep understanding of what is implied by either one of them.

The absence of a unified position from the Catholic Church on local mystical practices was also mentioned as a reason why Timorese people have not broken from their kultura. The absence of a unified position is considered to be a product of the diversity and fragmentation of kultura on a national scale. As my sources suggested, the lack of an official Church position contributes to a situation in which phenomena that - from an outside perspective - could be considered contradictory are not experienced that way in local daily life. An example is the presence of Catholic priests at inauguration ceremonies for sacred houses or for sepulchres in the backyards of Dili houses. Members of the Catholic Church participating in events dedicated to the cult of local mystical entities is seen to confuse people, making it difficult for them to interpret and experience Christian conversion as a break from kultura.

During the Dili fieldwork, I participated in events named as kultura in which priests were present. I even witnessed a case in which a priest acted as a lia-nain (ritual speaker) to negotiate his niece's marriage exchanges, communicating to the fetosaa (wife-takers or the husband's family) what the bride's family expected as gifts. Positions such as these are at times justified to corroborate the project that Christianity be seen as part of kultura, not something that is in opposition to or separated from it. I will return to this question later.

\section{Cultural policies}

One of my interlocutors perceived the state's appreciation of kultura as preventing true Christian conversion of Timorese people. The country's constitution attributes a positive value to kultura and public policies that provide financial support and special acknowledgement from the state exist to reconstruct sacred houses (Fidalgo Castro 2015). These facts are interpreted by some Catholic priests as weakening the Catholic Church in Timor-Leste since they place kultura and the Church on an equal footing. 
In this context, the policies of a laic state - backed by the socialist Fretilin party during its time in government - is frequently quoted as a political challenge to the Church. The conflict between the Church and the Fretilin Government in 2005, concerning the policy to make religious education optional in schools, is mentioned as an example of public policies aimed at weakening the Catholic Church. Others presented the conflict as showing a lack of respect for the role of the Catholic Church leadership in the resistance to Indonesian occupation (Silva 2008). One of my interlocutors associated Fretilin's projects with the Cuban Government's actions in that country after the revolution. It revived the local culture to weaken the Church. Note that for this interlocutor, kultura and Christianity were like oil and water: they should not be mixed.

The political and economic interests of older people involved in ritual exchanges are also mentioned as reasons for the absence of rupture between kultura and Christianity. Given that kultura entails the circulation of goods and money, the older people of the families who, according to custom, should receive these resources, work to reproduce kultura because it benefits them.

\section{The religious experience in question: Aesthetic performance or interiority?}

What are perceived as East Timorese mentalities are also mobilised to make sense of the way people experience Christian life. The Catholic priests I interviewed for this chapter suggested that, according to East Timorese converts, you would become a Christian simply by affirming that you were one. The newly converted parishioners were not interested in gaining a rational understanding of Christianity or to assume an exclusive commitment to its precepts.

In early 2013, the then Bishop of Dili, Dom Ricardo, travelled to Liquiçá district to prepare young people for confirmation. To evaluate the youths' understanding of the sacrament they would receive, the Bishop chose five teenagers and asked them about the dogmas that would be confirmed. None of those chosen were able to respond correctly. Disappointed, the Bishop cancelled the ceremony and ordered all of them to return to the preparatory course. My interlocutor presented the event as an example of the superficiality of East Timorese people's adherence to Christianity. 
In his comparative work about Christianity in Ataúro, Boarccaech (2013) discussed a fact that cast light on features that characterise certain East Timorese people's adherence to Catholicism. To select a religious education teacher in the subdistrict of Ataúro in 2009, the Catholic Church issued a test to measure the candidates' biblical knowledge. Most of them were catechists and masters of the Eucharist. However, the test grades showed that none had sufficient knowledge of the Bible to be able to teach religion.

The five Timorese priests - my interlocutors - suggested that, for most people in their country, being Christian only implied taking part in events of the Christian liturgy, such as the mass, praying the rosary and walking in processions. People were neither concerned about rupture with kultura nor with any changes in worldview. The priests saw these facts as a challenge to overcome, to lead people to achieve a more active and aware engagement with Christianity. This diagnosis has engendered projects such as that presented in the book 50 anos da paróquia Sagrado Coração de Becora (Fifty years of the Sacred Heart of Becora Parish) (Silva et al. 2015), a systematic history of the parish and its future plans. The book states that the Church's main challenge is to attract Christians to its regular activities, so they are more active in the institution and thus deepen their faith. The book presents the reactivation of the parish's pastoral council as an essential strategy for making the lay members more engaged with the Church and Christianity. It explains:

The pastoral council allows those who are baptised to know more and love Jesus Christ more, living according to the Gospel, in words and deeds. The meetings ... in the parish are important for them to find their identity and for the quality of their actions. (Silva et al. 2015: 84)

Despite the narratives discussed herein, it is possible for us to interpret the quality of Timorese people's commitment to Christianity in a more positive and less ethnocentric way. As Keane (2007) recalls, the way people conceptualise, experience and reproduce their relation with mystic, supernatural entities and/or other domains of existence (phenomena phased as religion by certain western epistemology) is always a cultural construction. The expectation that religious practice is based on faith, in which external actions are a product of internal and sincere dispositions cannot be universalised. This particular idea, according to Keane, is a Calvinist construction. The understanding that religion concerns a set of subjective beliefs, and not material forms and rituals, was established and 
consolidated during the Protestant Reformation (ibid.: 67). Protestantism promoted the subordination of external expressions of faith to internal belief (ibid.: 75). Apparently, such subordination and expectation are also shared among the Catholic priests I interviewed.

To explain the way Timorese people experience Christian religiosity, one of my interlocutors affirmed that many people live as Christians based on the ideas that guide their relations with local spiritual agents. There is a sort of projection of meanings and expectations from the realm of kultura to the realm of Christianity. In another publication, I hypothesised that religious experiences in Timor-Leste may be thought of as aesthetic management and contemplation, 'given the compulsory nature of its materialisation, highly regulated in the form of rituals where words, relics, sacrifices, and gifts have agency, especially in the Lulik [sacred] universe' (Silva and Sousa 2015: 7-8).

The impact of kultura and my interlocutors' political anxieties formed the context for their demands, which were framed by expectations of deep changes in the way their compatriots experience their religion. From superficial and formal experience, they believed it should become deep and present in actions in daily life, shaping individuals' internal dispositions. According to the priests I interviewed, religion and culture should be two separate domains, echoing Latour's (1994: 16) description of modernity's drive towards 'purification', according to which material and spiritual spheres need to be neatly separated from one another. There was a need to make the Christian God the sole object of worship, to whom faith and power are attributed. Finally, instead of centring on ritual performance, the religious experience should be based on faith. Therefore, more important than converting people to Christianity through baptism, the pastoral tactic of the Church in the post-independence context has been to 'evangelise the baptised'.

\section{Pastoral practices for re-evangelicalising: Policies for the relationship between kultura and Christianity}

The non-rupture with kultura observed among East Timorese people who adhere to Christianity is a source of frustration for the Catholic Church clergy. This frustration has given rise to different pastoral praxis, aimed at 
enabling East Timorese people to achieve true conversion. Until now, my field studies have identified three ideal types of pastoral projects concerning the relationship of kultura and Christianity. Project One: making a tactical use of kultura in order to strengthen Christian conducts. Project Two: foster the enduring coexistence and mutual reinforcement of kultura and Christianity, with some selectivity. Project Three: banning kultura because of its supposed incompatibility with Christianity. In this section, I analyse practices and discourses that illustrate each of these three projects. As ideal types, these projects do not exist in a pure form. Moreover, the ideologies that define them, as well as their effects, may overlap.

The respect and appreciation for what the Catholic Church identified as kultura in the mid-1960s, at the conclusion of Vatican Council II, should be a guide for the different pastoral practices of this institution throughout the world. This project was cited by two of my interlocutors who belong to religious orders that have historically used local social reproduction practices to support the introduction of Christian knowledge and behaviour. According to them, it is possible to find the principles of Christianity in most societies, and these existing beliefs should be used to promote the conversion of people. These two sources respectively belong to the Jesuits and Divine Word Missionaries (SVD [Societas Verbi Divini]). Both clerical orders are known for making good use of local institutions to introduce Christianity.

In 2012, Father Adriano Ola published an example of the pastoral practice through which elements of the local mystic repertoire are used to introduce Christian conducts or particular visions of the Catholic Church in Timor-Leste. The article 'Fila ba Isin Lolon' ('The return to the body') - in number 14 of the Revista Seara, in a section entitled Pastoral Affairs calls for Catholics to pay attention to their bodies because the body is the home of the holy spirit (Ola 2012). The text's central argument consists of emphasising control over the body, particularly of sexuality, to avoid contracting HIV/AIDS. It is a pedagogical narrative designed to inculcate in readers control over sexuality so that sexual relations are restricted to marriage and monogamous relationships. In this context, HIV/AIDS is presented as a punishment from God for men and women who allegedly do not respect their bodies because they have sex before marriage or are not monogamous. As indicated above, most people are not celibate as it is quite common for couples to live together and have children before marriage in Church. Given this, a major aspect of the proposed conduct is unusual for most people. 
The narrative tactic Ola uses to sustain his argument is as important as the argument itself. The article is divided into four sections, which are framed to produce homologies between the Catholic Church and the sacred houses, and analogies between Christianity and kultura. In the first section, entitled Timor nia uma lisan (Traditional Houses of Timor), the author argues that the Catholic Church is the shelter - the support structure for traditional houses. Based on evocations of complementary dualism that characterise the ritual poetry in Eastern Indonesia and Timor-Leste (Fox 1988), Ola suggests that nothing in the world is isolated and absolute - everything needs an opposite to generate balance. What the priest appears to be saying is that the Catholic Church and the uma lisan are complementary. It is the relationship between them that generates equilibrium.

In the next section, Uma kreda (The Church), Ola suggests that each Christian embodies the Church itself. The Church lives in each one of us and Christ is presented as the head of the matebian (deceased relatives). He also writes that baptised people should base their faith on the resurrection of Christ. If there is no faith in Christ's and our own resurrection, life loses meaning.

In the third section, entitled Isin lolon, uma kreda no tradisaun Timor (Body, Church and Timorese Tradition), Ola argues that lisan (tradition) serves to fertilise and reproduce the world, in all its senses. The function of the prayers that the lia-nain make to their ancestors is the same as the prayers that baptised people make to God; all are conducted to promote the fertilisation and reproduction of life. In this section, he uses as a metaphor the action of sowing. The ritual practices, Christian or pagan, have the objective of sowing to guarantee reproduction and fertility.

In the fourth section, entitled Problema Ne'ebe ita hasoru (The Problem that We Encounter), Ola presents the contemporary world immersed in crisis. This crisis is generated by the lack of attention to the body as the temple of the Church and of God. He then presents HIV/AIDS as a consequence of people's lack of respect for their bodies, portraying it as a curse, a spell or a punishment from God.

Finally, Ola concludes by affirming that lisan and Christianity serve the same ends: lisan helps people to connect with each other and to find balance, as does the Church and Christianity. Thus, a homologous conclusion is: just as a consequence of not observing kultura is disease and even death, disrespect for Christian precepts generates punishments, such as HIV/AIDS. 
We observe that the author uses both local and Christian cultural references to make the facts he is reporting intelligible to the reader. Ola mobilises Christianity and elements of local cosmologies to establish mutual clarifications, although he emphasises the elucidation of Christian elements and the suggestion that HIV/AIDS is God's punishment. At first, the author uses complementary dualism to suggest that the relationship between Christianity and kultura (which he calls lisan) is not exclusionary. He affirms that these institutions, though within a hierarchy, are complementary. Ola suggests that the Church encompasses lisan, reinforcing the idea in the following section where he indicates that Jesus is the chief, the head of the matebian. Therefore, he does not deny the existence of the matebian but only suggests that Jesus is above them commanding them, as the Church hosts all the uma lisan. He then argues that the functions of the prayers made in a church and by the lia-nain are the same: part of the quest for fertilisation and reproduction. Ola later resorts to the rationale that interprets illness as the mystical agents imposing punishment - present in the local networks of causality - to give meaning to the appearance of HIV/AIDS. The subtext of the article is this: active sexuality before or outside of marriage is disrespectful to the body. True Christians should restrict their sex life to marriage and should remain celibate until they marry in Church.

A second project, which can be understood as a radical version of the first, proposes the continuing coexistence between kultura and Christianity. This is not just a temporary and tactical use of kultura for pedagogical purposes. This is an explicit intention for Christianity to encompass and encapsulate kultura to keep kultura alive, to reproduce it because it is considered a source of identity. Therefore, the Catholic Church should immerse itself in the local culture ('to inculturate'). Father Matheus, the rector of the Balide parish in 2008, raised this vision in an interview with the newspaper $A$ voz da Cultura.

In the interview, entitled 'As normas da cultura não são contraditórias com a doutrina de Jesus' ['The norms of culture do not contradict the doctrine of Jesus'], published on 5 May 2008, Father Matheus suggested that kultura and Catholicism are both monotheistic and allow for the recognition of a single higher God (Maromak) (Afonso 2008). To support this argument, the priest proposed that kultura allows people to be in contact with the spiritual world. Nevertheless, kultura does not reveal to people who their 
supreme ancestors are. It is the Church that does that; the Church reveals that Maromak is the highest of the spirits through the revelations of Jesus Christ.

According to Father Matheus, many local religious practices are found in the Bible. He used the example of animal sacrifice. The priest argued that it originates with Abraham as a teaching of God. The priest presented inculturation as the Church's most important pastoral practice, initiated by the incarnation of God in the form of Jesus Christ. Father Matheus described the ontological transformation of God into Man - through His incarnation in Jesus $\mathrm{Christ}^{7}$ - as the greatest sign of the need for the Church's inculturation. He interpreted the incarnation of God in the form of man as an inculturation of God.

Father Matheus affirmed that the mission of inculturation is to show that all kulturas have a positive value and that they have good, positive messages/learnings. Kultura would improve if it evolves, taking Jesus Christ into consideration. To do so, some adjustments may be necessary, such as the recognition that Maromak is the supreme ancestor.

According to Father Matheus, some of Jesus's teachings imply the need for an adjustment in kultura. The priest highlighted that this does not mean losing kultura. For example, the custom of giving food to the dead must stop because the dead, as spirits, do not have bodies that need to eat. To avoid contradictions emerging between kultura and Christianity, the priest also suggested that people should seek greater knowledge about kultura and about Jesus Christ. He said that one cannot stop practising kultura because Maromak is the foundation for the ancestors. For Father Matheus, kultura is a pathway to attain Maromak and should be maintained because it lies at the base of peoples' identity.

Other Timorese priests defended an opposite pastoral tactic. They suggested that for people to convert truly to Catholicism, it is necessary to eliminate from its liturgy any reference to local religious practices or entities. Also, the presence of local musical instruments or religious songs must not be permitted. In a certain way, such a project resonates expectations and practices shared among most of Christian missionary agents prior to Vatican Council II acting in the Portuguese Timor (Bovensiepen and Rosa 2016). For them, local beliefs in lulik powers were

7 I owe this insight to Daniel Simião. 
incompatible with Christian values and liturgy. Nevertheless, one of my interlocutors indicated that this position is very difficult to maintain due to the very engagement of the Timorese clergy with local institutions and beliefs.

Most of the Catholic priests I spoke to criticised a position of intolerance or unwillingness to negotiate or understand kultura. They said that this lack of knowledge or intolerance present in some of the local clergy was formerly promoted by conservative priests sent to Timor-Leste during Portuguese colonialism. The distant relationship some of the local clergies had with communities resulted from the conservative character of the Catholic Church in Portugal, which acted as the main ideological apparatus of the colonial state. Moreover, my interlocutors suggested that priests have greater or lesser tolerance of local institutions depending on the religious orders to which they belong. Those with clerical orders that have a history of working with techniques of inculturation would mostly be sympathetic to dialogue with kultura.

In this context, references to Protestants frequently emerge. Many of my interlocutors propose that Protestants are much more severe and demanding with their converts, compared with the greater tolerance of the Catholic Church to local practices. In fact, the work of Boarccaech (2013) confirms this hypothesis for the case of Ataúro.

In addition to the Catholic Church's greater tolerance or respect for the local religious practices and knowledge, the greater adherence of the Catholic Christians to kultura might be explained, at least partially, as a product of how the clergy engage with local communities. In many rural villages, the presence of a priest is rare. At most, he visits a village once a week, or when he is called to give the sacraments; he then leaves, due to pastoral choices or institutional commitments elsewhere. In contrast, the Protestant pastors are much more present. Many of them live permanently in the villages, thus allowing closer and more demanding pastoral oversight. Moreover, I observed that my younger interlocutors had a greater willingness to accept kultura than the older ones. 


\section{Conclusion: The future of Christianity in Timor-Leste}

There was some agreement between my clergy interlocutors, despite the differences framing their pastoral projects and praxis. All of them referred to kultura and Christianity as exclusive moral realms and considered most East Timorese people's adherence to the latter as shallow. In other words, at the time of my research, all of them recognised the fact that Christianity did not encompass kultura and that religion and kultura were different domains of action. Although they shared assumptions, they also pointed to diverse ideal arrangements for the relationship between these two moral orders. To conclude, I discuss some comparative examples from Indonesia and Melanesia in order to think critically about the disparate pastoral visions about the future of the relationship between religion and kultura discussed in this chapter.

In the introduction, I suggested that the project supporting the mutual enforcement of kultura and Christianity may nourish an understanding of culture that considers religion a realm of action separate from kultura. On the one hand, such an arrangement evokes the image of culture as a mosaic, made up of the sum of diverse domains of action that do not overlap, similar to that which Howell (2001) identified among the Lio on the island of Flores and other people in Indonesia.

On the other hand, the current encompassment of Christianity by kultura, criticised by my interlocutors and discussed throughout the chapter, recalls a common way of making sense of such a relationship in parts of Melanesia. According to Tonkinson (1982), Christianity is part of kastom (custom) in Vanuatu, for instance. The two are not thought of as exclusive domains of action since Christianity (religion) is contained in kastom. Conversely to the image of a mosaic, kastom and religion relate one another as an alloy, as an amalgam. Opposing that, many of the clergy in Timor-Leste work for Christianity to encompass kultura, using the latter in a tactical way. Father Adriano Ola's article in Revista Seara is an example of that praxis.

However, the understanding that conversion involves a rupture with a previous and supposedly inferior moral order is very much present in the higher Catholic clergy and among other Christian denominations. For many people, the coexistence of kultura and Christianity must be 
overcome. Such an objective is pursued by derogatory discourses about local ways of life and beliefs that nourish negative representations and a troubled self-awareness for East Timorese people. Whatever the future arrangements between kultura and religion will be, the projects and practices this chapter explores have already played a role in shaping them.

\section{References}

Afonso, Matheus (2008). 'The norms of culture is not contradict with doctrine of Jesus [sic]', Interview by Father Matheus in A voz da Cultura, 5 May, p. 6.

Barnes, S. (2010) 'Nation-building and the "resurgence of custom"', in Grenfell, D., Walsh, M., Soares, J., Anselmie, S., Sloman, A., Stead, V. and Trembath, A. (eds) Nation-building across the urban and rural in Timor-Leste, Conference Report, Melbourne University: RMIT, pp. 12-14. Available at: cultura.gov.tl/ sites/default/files/Conference_report_English_web_combined.pdf.

Boarccaech, A. (2013) A diferença entre os iguais [The difference amongst the equals], São Paulo: Editora Porto das Ideias.

Bourchier, D. (2007) 'The romance of adat in the Indonesian political imagination and current revival', in Davidson, J. S. and Henley, D. (eds) The revival of tradition in Indonesian politics: The deployment of adat from colonialism to indigenism, London: Routledge, pp. 113-129. doi.org/10.4324/ 9780203965498.

Bovensiepen, J. (2015) The land of gold: Cultural revival and post-conflict reconstruction in independent Timor-Leste, Ithaca: Cornell University Press, Southeast Asia Program Publications.

Bovensiepen, J. and Rosa, F. D. (2016) 'Transformations of the sacred in East Timor', Comparative Studies in Society and History, vol. 58, no. 3, pp. 664-693. doi.org/10.1017/s0010417516000311.

Davidson, J. S. and Henley, D. (2008) 'In the name of adat: Regional perspectives on reform, tradition, and democracy in Indonesia', Modern Asian Studies, vol. 42, no. 4, pp. 815-852. doi.org/10.1017/s0026749x07003083.

Durand, F. (2004) Catholicism et protestantisme dans liilê de Timor: 1556-2003 [Catholicism and Protestantism in Timor Island: 1556-2003], Toulouse, Bangkok: IRESC. 
Fernandes, A. J. M. (2014) 'Em searas do Timor Português: Um estudo sobre as práticas de mediação da Diocese de Díli no período colonial (1949-1973)' [The Seara newsletter of Portuguese Timor: A study on Dili Diocese mediation practices in colonial times (1949-1973)], Dissertação de Mestrado [Master's dissertation], Universidade de Brasília.

Fidalgo Castro, A. (2015) 'Objetos incómodos: El lugar de las "uma-lulik" en el Estado-Nación de Timor-Leste' [Uncomfortable objects: The place of the 'uma-lulik' in the Timor-Leste state building], Cadernos de Arte e Antropologia, vol. 4, no. 1. Available at: cadernosaa.revues.org/849. doi.org/10.4000/ cadernosaa.849.

Foucault, M. (2008) Segurança, território, população [Security, territory, population], São Paulo: Martins Fontes.

Fox, J. (1988) 'Introduction', in Fox, J. (ed.) To speak in pairs: Essays on the ritual languages of Eastern Indonesia, New York: Cambridge University Press. doi.org/10.1017/CBO9780511551369.001.

Howell, S. (2001) 'Recontextualizing tradition: "Religion", "state” and "tradition" as coexisting modes of sociality among the northern Lio of Indonesia', in Liep, J. (ed.) Locating cultural creativity, London: Pluto Press, pp. 144-158. doi.org/10.2307/j.ctt18fs9q6.15.

Keane, W. (2007) Christian moderns. Freedom and fetish in the mission encounter, Berkeley: University of California Press.

Latour, B. (1994) Jamais fomos modernos [We have never been modern], Rio de Janeiro: Editora 34.

Mamdani, M. (1998) Ciudadano Y súbdito: África contemporánea y el legado del colonialismo tardio [Citizen and subject: Contemporary Africa and the legacy of late colonialism], Madri: Siglo XXI Editores.

McWilliam, A., Palmer, L. and Shepherd, C. (2014) 'Lulik encounters and cultural frictions in East Timor: Past and present', The Australian Journal of Anthropology, vol. 25, no. 3, pp. 304-320. doi.org/10.1111/taja.12101.

Ola, A. (2012) 'Fila ba Isin Lolon', Revista Seara 14.

Palmer, L. (2015) Water politics and spiritual ecology: Custom, environmental governance and development, London: Routledge. doi.org/10.4324/9781315 883250 .

Robbins, J. (2004) Becoming sinners: Christianity and moral torment in a Papua New Guinea society, Berkeley: University of California Press. 
Roque, R. (2011) 'Etnografias coloniais, tecnologias miméticas: A administração colonial e os usos e costumes em Timor-Leste no final do século XIX' [Colonial ethnographies, mimetic technologies: Colonial administration and customs in late nineteenth century Timor-Leste], in Silva, K. and Sousa, L. (eds) Ita maun alin: O livro do irmão mais novo. Afinidades antropológicas em torno de Timor-Leste [The younger brother's book. Anthropological affinities around Timor-Leste], Lisboa: Ediçóes Colibri, pp. 155-168.

Silva, A. et al. (2015) Tinan 50 parokia Sagrado Coração de Jesus Becora [50 Years of Sagrado Coração de Jesus Becora Parish. From a missionary church to a people's church], Husi igreja Missionário ba Igreja Povu Nian: Dili, Offcet Sylvia Dili.

Silva, K. (2008) 'The Bible as constitution or the constitution as Bible? Nationstate building projects in East Timor', Horizontes Antropológicos, vol. 4, pp. $1-16$.

Silva, K. (2013) 'Negotiating tradition and nation: Mediations and mediators in the making of urban Timor-Leste', The Asia Pacific Journal of Anthropology, vol. 14, no. 5, pp. 455-470. doi.org/10.1080/14442213.2013.821155.

Silva, K. (2014) 'O governo da e pela kultura: Complexos locais de governança na formação do Estado em Timor-Leste' [The government of and through kultura: Local clusters of governance in Timor-Leste state building], Revista Critica de Ciências Sociais, vol. 104, pp. 123-150. doi.org/10.4000/rccs.5727.

Silva, K. and Simião, D. (2012) 'Coping with "traditions": The analysis of EastTimorese nation building from the perspective of a certain anthropology made in Brazil', Vibrant, vol. 9, no. 1, pp. 361-381. doi.org/10.1590/S180943412012000100013.

Silva, K. and Simião, D. (2017) 'Negotiating culture and gender expectations in Timor-Leste: Ambiguities in post-colonial governance strategies', in Niner, S. (ed.) Women and the politics of gender in post-conflict Timor-Leste: Between heaven and earth, Oxford: Routledge. doi.org/10.4324/9781315657387.

Silva, K. and Sousa, L. (2015) 'Art, agency and power effects in East Timor: Provocations', Cadernos de Arte e Antropologia, vol. 4, no. 1, pp. 3-16. Available at: cadernosaa.revues.org/829. doi.org/10.4000/cadernosaa.829.

Tonkinson, R. (1982) 'Kastom in Melanesia: Introduction', Mankind, vol. 13, no. 4, 302-305. doi.org/10.1111/j.1835-9310.1982.tb00995.x. 
This text is taken from The Promise of Prosperity: Visions of the Future in Timor-Leste, edited by Judith Bovensiepen, published 2018 by ANU Press, The Australian National University, Canberra, Australia.

doi.org/10.22459/PP.2018.12 